\title{
The Thoughts of Economic Growth Theories of Classical Muslim Scholars, A Contribution
}

\author{
Tubagus Thresna Irijanto ${ }^{1}$ \\ Mohd. Azlan Shah Zaidi ${ }^{2}$ \\ Abdul Ghafar Ismail ${ }^{3}$ \\ Research Centre for Islamic Economics and Finance \\ School of Economics \\ Universiti Kebangsaan Malaysia \\ Bangi, 43600 Selangor Darul Ehsan, Malaysia \\ E-Mail: thresna71@gmail.com
}

\begin{abstract}
This paper attempts to view at the development of Islamic thought in the study of economics and economic growth. In particular, it attempts to explore the similarities and differences between Islamic ideas about economics and to construct economic growth thought and how it used to bridge the gap. The analysis starts from Muslim thought Ibn Khaldun, Al-Ghazali and Ibn Taymiyyah. In addition, the study looked at how the views of classical Islamic scholars had entered into the idea of economic growth. Suggestions will be made on how the gap can be bridged or made closer to contemporary economic thought and economic direction of the country's future.
\end{abstract}

Keywords: classical muslim scholars, Al-Ghazali, Ibn Taymiyyah, Ibn Khaldun, economics thought, economic growth theory.

1 Researcher in Islamic Economic, Faculty of Economic and Management, Universiti Kebangsaan Malaysia

2 Associate Professor, Faculty of Economic and Management, Universiti Kebangsaan Malaysia

3 Professor of Banking and Financial Economics, School of Economics, Universiti Kebangsaan Malaysia. He is also Research Director of IRTI IDB, Principal Research Fellow, Institut Islam Hadhari and AmBank Group Resident Fellow for Perdana Leadeship Foundation.We would like to acknowledge the research grant UKM-AP-2011-06 


\section{INTRODUCTION}

Most discussion of the economic growth model refers to the idea and model of the neoclassical school, for example Sollow models, which bases its economic growth thought to factors such as the accumulation of capital and depreciation, labor and population growth, and technological advances inherent in labor, and may also be some other ideas that come from a similar classical thought, say for example in conventional economic thinking. On the other hand we may ask, how do classical Muslim scholars regarding the thinking of economic growth? And how their opinions with regard to the growth factors? Is there a different mindset, or are there similarities?

Studies on thoughts of the classical Muslim scholars in the field of economic growth seems very limited and few, but perhaps just a lot of ideas from them regarding the ideas of economic growth or the factors that led to the economic growth of a country's economy. As far as we get that the thought of Ibn Khaldun was a much studied and quoted with respect to economic growth.

Due to few and limited study of ideas and thoughts of economic growth of the classical Muslim scholars to be one of the factors which led us to revisit and reexamine their thoughts and ideas in terms of economic growth as part of their contribution. Other reasons which became the basis study of ideas and their thought are caused by the differences epistimologi of thoughts and ideas of the classical Muslim scholars, which they based on the values and morals that comes from revelation, besides the reality condition that occurs in a positive. They also provide a comprehensive thought, linking the economic aspects to the non-economic aspects, for example social and political aspects of society, and other aspects of it, especially trying to relate the physical and nonphysical aspects and values of divinity with the idea of economic growth, not just for this life and physical material but also spiritual life and the hereafter as well as non-physical.

A small portion of modern thought has begun to try to relate the thought of economic growth with the dimension of time, for example by considering the present to future generations, as described in its intergenerational models, however these models are still just discussing the scope of the current time dimension in world without linking aspects of life after this world or the hereafter, There are also thoughts about the economy and economic growth which tried to relate to moral values, for example by the value of the moral and ethical values of Buddhism, or tried to relate to the environment and natural balance. The thoughts and ideas of these kind which developing in modern times, indicated which attempts to connect moral values or religious in economic growth and economic development of societies or countries.

This study attempted to reconstruct the economic thought and economic growth of the classical Muslim scholars of Al-Ghazali, Ibn Taymiyya and Ibn Khaldun. Our motivation to choose the classical Muslim thinkers and scholars are based on the views of Islamic values and the values of their thoughts, that they started the discussion by grounding the Islamic viewpoint and Islamic values in assessing aspects of economic behavior and economic growth.

In this paper, we might discover the differences between their ideas and thoughts, but we also try to find similarities and connections of ideas and thoughts. Our effort here is to obtain a more comprehensive understanding of their thoughts and ideas in the field of economics and its relation to economic growth, which in turn will provide an overview and a contribution to the study of modern economic ideas from Islamic scholars.

In the modern context, the idea of the classical Muslim scholars and thinkers has been much discussed and reviewed in modern economics, it means there is a similarity and resemblance that may occur. This study attempted to explore the ideas of classical Muslim scholars in the field of economic thought and tried to analyze and connect with the idea of economic growth.

Discussion in this study is divided into two major sections, the first section discusses the ideas and economic thought of Muslim scholars started from Al-Ghazali, Ibn Taymiyya and Ibn Khaldun, while the second part will discuss and examine thoughts of a third scholars the classical Muslim, in relation to economic growth and development thoughts associated with their ideas, which are discussed in the first part separately, which is expected to see the flow of ideas regard their economic reasoning separately and relation to sustainability ideas and thoughts among the classical Muslim scholars, and then discuss the ideas of thought in relation to the ideas and thoughts of economic growth in a more comprehensive way. 


\section{METHOD}

\section{Systems Thinking}

Systems Thinking has at least some roots in the General System Theory that was advanced by Ludwig von Bertalanffy in the 1940s and furthered by Ross Ashby in the 1950s. The term Systems Thinking is sometimes used as a broad catch-all heading for the process of understanding how systems behave, interact with their environment and influence each other. The term is also used more narrowly as a heading for thinking about social organisations, be they natural or designed, healthy or unhealthy. Often the focus is on a government or business organisation that is viewed as containing people, processes and technologies.

Systems thinking has been applied to problem solving, by viewing "problems" as parts of an overall system, rather than reacting to specific parts, outcomes or events and potentially contributing to further development of unintended consequences. Systems thinking is not one thing but a set of habits or practices within a framework that is based on the belief that the component parts of a system can best be understood in the context of relationships with each other and with other systems, rather than in isolation. Systems thinking focuses on cyclical rather than linear cause and effect.

In systems science, it is argued that the only way to fully understand why a problem or element occurs and persists is to understand the parts in relation to the whole. Standing in contrast to Descartes's scientific reductionism and philosophical analysis, it proposes to view systems in a holistic manner. Consistent with systems philosophy, systems thinking concerns an understanding of a system by examining the linkages and interactions between the elements that compose the entirety of the system.

Systems science thinking attempts to illustrate how small catalytic events that are separated by distance and time can be the cause of significant changes in complex systems. Acknowledging that an improvement in one area of a system can adversely affect another area of the system, it promotes organizational communication at all levels in order to avoid the silo effect. Systems thinking techniques may be used to study any kind of system - physical, biological, social, scientific, engineered, human, or conceptual.

\section{System Dynamics as a Theory Building Method}

System dynamics is a modeling and simulation method that relies on a variety of qualitative and quantitative data sources in the formulation of dynamic theories (Richardson \& Pugh, 1981; Sterman, 2000). The premise is that dynamic behaviors (performance over time) are closely linked to an underlying structure of feedback loops. Articulating and understanding linkages between behavior and structure contributes to our understanding of the world, and constitutes away of creating theories about the word that we call Dynamic Hypotheses.

Similarly to other qualitative theory-building approaches (Eisenhardt, 2002; Glaser \&Strauss, 1967; Walsham, 1995), "a formal model is constructed by inferring from data and theoretical statements some hypotheses about causal relationships that generate a particular pattern of behavior over time observed in the case. Model -building proceeds iteratively by representing the hypotheses in a mathematical form, simulating, comparing the model output with observed behaviors, and returning to the observations and theories to refine the hypotheses represented in the model by changing its structure. In this sense, a formal model is a non-textual, mathematical expression of a theory of the cause-and -effect relationships that systematically produce the patterns of behavior observed in the field" (L. Black, 2002, p. 120). The mathematical nature of the method forces the analyst to be "quite exact and specific in attempting to specify causal dynamics that accomplish a satisfactory translation between verbal theory and empirical observations" (Hanneman \& Patrick, 1997, p. 457).

Dynamic simulation has been argued to constitute an effective way for building theories about social phenomena. For example, McCaffrey and his colleagues (1985)showed how the use of simulation could contribute to solve apparent contradicting conclusions between regression research and case studies in Public Administration by better understanding the dynamics of key performance variables used in both kinds of research. Sociologists such as Patrick (1995), argues that dynamic simulation helps to get a better understanding of verbal theories and any unexpected outcome obtained from them, with the potentiall to inform or improve the activities of both, theorists and empirical analyst. 
More recently and consistent to these views, Davis and his colleagues (2007) also argue for the use of simulation methods as a way to use a synthetic environment to incorporate our knowledge about a particular phenomenon to refine our understanding of the problems and better focus further empirical research efforts.

System dynamics has proven useful for studying complex feedback systems (Richardson, 1996). In the concrete case of theory -building efforts, system dynamics has been successfully used in sociology (Hanneman, 1987; Patrick, 1995), management and organizational theory (Black, Carlile, \& Repenning, 2004; Rahmandad, 2008, 2012; Repenning, 2002), information systems (Abdel-Hamid \& Madnick, 1990; Duhamel, Gutiérrez-Martínez, Picazo-Vela, \& Luna-Reyes, 2012)and public administration (Ghaffar zadegan \& Andersen, 2012; Luna-Reyes \& Gil-Garcia, 2011).

\section{FINDINGS AND DISCUSSION}

\section{The Ideas of Classical Muslim Scholars on Economic Thought}

The discussion in this section will be divided according to earlier scholars till the latest scholars. It means that we will start from Al Ghazali (450-505 H/1058-1111 M) followed by Ibn Taymiyyah (661$728 \mathrm{H} / 1262-1328 \mathrm{M})$, and Ibn Khaldun (732-808 H/1322-1406 M).

\section{Al Ghazali Economic Views}

Al-Ghazali was not only a Muslim philosopher, theologian, jurist and mystic of Persian descent, but he was also an expert in the field of economy, especially about the ethics of Islamic finance. ${ }^{4}$ Nejatullah Muhammad Siddiqi (1992) in his book Reading on Islamic Economic mentioned the name of al-Ghazali in a row of the Muslim economic thinkers together with Ibn Taymiyya, Ibn Khaldun and other figures. ${ }^{5}$ During this period, the discourse of Islamic economics had grown extensively and was characterized by the expansion in the Muslim empire.

4 Abū Hāmid Muhammad ibn Muhammad al-Ghazālī (c. 1058-1111); known as Al-Ghazali or Algazel to the Western medieval world, see The Columbia Encyclopedia (2012), 6th ed. Columbia University Press. Retrieved 17 April 2013.

5 This idea was also mentioned by other scholars such as Ghazanfar, 2003, Ghazanfar, S.M. Medieval Islamic Thought: Filling the "great gap" in European Economics. London: Routlegde, 2003.
Complexion of Islamic economic thought at that time focused on micro-economic analysis and the functions of money. Al-Ghazali, for example, has alluded to money, its function, and evolution of its use. He also explained the issue of prohibition of riba and its impact on the economy of a nation.

On microeconomic analysis, he discussed the issue about weight scales, price controls (at-tas'is or intervention), the determination of tax in certain circumstances or emergencies. He also talked about how did the economy cope with the impact of rising prices. Could it be done via the market mechanism or government intervention, and others.

Bernand Lewis (1993) asserts that the concept of Al-Ghazali exhibit a distinctive character, given the philosophical nuances thickened due to the influence of mystical science base. However, the interesting part of the financial outlook is that al-Ghazali was not stuck on the plains of philosophical, but rather shows a harmonious mix between real condition that belongs to people with philosophical values and accompanied by a logical and clear arguments.

Al-Ghazali's economic thought at least covers the basic concepts of the behavior of individuals as economic agents, such the concept of property, the concept of social welfare (outweigh), market evolution, demand and supply, prices and profits, market values and ethics, production activities and hierarchies, barter system and functions of money, and the function of the state in the economy.

Al-Ghazali said that, engages in legal economic activities were fard kifaya. Economic activity must be based on the goal of happiness in the afterlife. Further he explains the reasons why people should engaged in economic affairs, namely: First, God has created an abundance of natural resources to be exploited by humans for its survival, as well as proof of gratitude to god for the sustenance Giver. Second, people who are economically powerful then his life will be free, away from dependence on others and can run perfectly religious teachings, such as zakat, infak, charity and pilgrimage.Third, the behavior of the economy in pursuit of fulfillment can not deviate from the teachings and principles of Islam.

Al-Ghazali stressed the importance for economic actors to have knowledge of the principles and rules of Islam in economic transactions. They must know the types of transactions that are prohibited and allowed. They should know about bai '(sale), usury, salam, ijara, mudaraba and musharakah. Every economic 
transaction has pillars and conditions that must be known by the business community in order to avoid vices and damages that may arise later on.

Al-Ghazali thought in socioeconomic is rooted in a concept that he calls "Islamic social welfare function". Of this concept was born the term masalih (utilities, benefits) and mafasid (disutilitas, damage) in a position to strengthen social welfare. According to Al-Ghazali, the welfare of the society will only be realized if it maintains five basic objectives, namely religion, life, intellect, property and offspring. Through these five basic goals, he then split three levels of individual and social utility, ie daruriat (needs), hajiat (pleasure), and tahsinat (luxuries).

So, the concept of welfare and vice have long put forward by Al-Ghazali before the concept developed in the modern economy with the term "social welfare". He said that every individual act that harms others including destructive acts. Examples of actions that harm the public interest and in the category of destructive acts according to Al-Ghazali were the hoarding of goods and falsify money. It was considered a destructive act because it affected the market imbalances that ultimately harm the interests of the general public.

Al-Ghazali also argued in detail about the process of the formation of the "market" naturally. The market formed by the drive to each other's needs. Al-Ghazali uses the term blacksmith, carpenter, and farmers to exchange ownership in order to meet their individual needs. Naturally will form a place called "the market" to exchange if the needs of each different. A1-Ghazali later found on the grounds of trade (exchange) there will be a movement of goods from one place to another. The main motive behind this activity is to raise capital and profits. Adam Smith (1723-1790) who lived 700 years after Al-Ghazali said that the term is almost similar to the view of Al-Ghazali when describing the process of formation of the market (the exchange), but uses a different term, namely butcher, brewers, and baker.

"It is not from the benevolence of the butcher, the brewer, or the baker that we expect our dinner, but from their regard to their own interest. We address ourselves, not to their humanity but to their selflove." (Adam Smith, The Wealth of Nation)."

Although Al-Ghazali was not much theorized about the law of supply-demand markets such as in the textbooks current economy, but many thoughts can be found in his book, especially Ihya 'Ulum al-Din that shows the depth of his understanding of the law of supply-demand market. For example, he said, "When a farmer can not find a buyer for their crops then he would sell it for less." (Ghazanfar, 1990,1997). A1Ghazali also is seems to know much about the 'priceinelastic "demand. This is evident in his advice not to take profits high in trade goods of basic human needs such as food.

"Money was created to facilitate the exchange in economic transactions."

Al-Ghazali deeply understands the function of money as a medium of exchange (medium of exchange). The exchange of goods and services will not be effective if only rely on barter system. This is where the benefits of God's creation called dinars and dirhams that have intrinsic value and can be used as a medium of exchange

Al-Ghazali said that: "possession of money (dinar and dirham) is not useful unless it is used as a means of exchange of goods and services." (Ghazanfar, 1997).

Money does not only serve as a medium of exchange but also as a measure of. Al-Ghazali reminds again that we should not practice usury, as in his words: "If one trade dinar and dirham to get the dinar and dirham, he made the dinar and dirham as the destination. This is in contrast to the function of the dinar and dirham. Money was not created to make money. Doing so is an offense. Dinar and Dirham is a tool to get other items. They are not meant for themselves. "(A1-Ghazali, Ihya 'Ulum al-Din).

Al-Ghazali also think about the functions of the State and the authorities in the regulation of economic activity. Economic progress will be achieved if there is justice, peace, prosperity, and stability. And this is the scope of the state's responsibility to make it happen. Furthermore, Al-Ghazali also talked about the concept of public finances. State revenues derived from zakat, fai, ghanimah and jizya. As for public expenditure, Al-Ghazali advocated the necessity of building socio-economic infrastructure that benefit can be felt directly by the people.

\section{The Concept of Money}

In his monumental work, Ihya 'Ulum ad-Din, alGhazali defines that money is the item or object that serves as a means to get other items. The object is considered to have no value as item (intrinsic value). Therefore, he likens the money as a mirror that does not have their own color, but can reflect all kinds of 
colors. Refer to these criteria, in terms of defining money, he not only emphasizes on the aspects of the functions of money. Such a definition is more perfect than the limits set out most of the more conventional economists define money that was limited to the functions inherent in money itself.

Therefore, according to Al-Ghazali money just as the standard price of the goods or things then money has no intrinsic value. Or more precisely the intrinsic value of a currency that is shown by his real existence has never been considered. Al-Ghazali's contention that money has no intrinsic value is ultimately related to the issues surrounding the demand for money, usury, and selling currencies.

First, the prohibition of hoarding money. In the Islamic concept, money is the public body that has a significant role in the economy. Therefore, when the money withdrawn from circulation, would lose an important function. For that reason, the practice of hoarding money strictly prohibited in Islam because instability will affect the economy of a society. According to Al-Ghazali the basic reason the prohibition of hoarding cash because such action would eliminate the inherent function of money. As mentioned, the purpose is to make money circulating in the community as a means of transaction and not to be monopolized by certain groups. In fact, the worst effects of the practicalities of hoarding money is inflation.

In this case, economic theory explains that the amount of money in circulation and the quantity of goods available at the same time close inverse relationship. If the money supply exceeds the amount of goods available, there will be inflation. Conversely, if the money supply was less than the items available there will be deflation. Both that economic diseases should be avoided so that between the money supply and the goods available in the market balanced.

Second, the problem of usury. In simple terms riba is addition to the principal capital obtained by way of vanity. Explicitly usury prohibition contained in the Qur'an Surat Al-Baqarah verse 275, 278-279, ArRum 29, An-Nisa '160-161, and Ali Imran 130. The fundamental reason of Al-Ghazali in the usury related to money is based on the purpose of the printed money itself, only as a medium of exchange and standard of value of goods only, not as a commodity. Therefore, the act of usury by way of exchange of the kind of money is out of the action that the original purpose of the creation of money and prohibited by religion.
Third, buying and selling currencies. One of the things included in the category of riba is buying and selling currencies. In this regard, Al-Ghazali's ban such practices. For him, if the practice of currency trading is allowed the same as letting someone else make money hoarding practices that will result in a scarcity of money in society. Since the sale, the money will only be circulating in certain circles, the rich people. This action was unjust. So a bit of a view of Al-Ghazali is filled with the spirit of universal humanity and Islamic ethics.

In the concept of money, Al Ghazali discussed money with regard to the function and role of money in the economy, where its function is as a tool in the transaction that should not be piled, nor should it be taken avail interest rate, and also allowed buying and selling currencies in limited scope or intended as a medium of payment of trade between countries. We shall analyze that Al Ghazali noticed money as a medium of transaction is more likely, even if the money was considered as capital, then it related to the role of money in the ability to produce goods and services, or in other words as a productive means of production, which in turn will be able to be a factor which spur the growth of the production of goods and services in the economy.

\section{Social Welfare Function}

Al Ghazali who stated that the needs of human life consist of three, the primary need (darruriyyah), secondary (hajiat), and a luxurious necessity (takhsiniyyat). Hierarchy of needs theory is then 'taken' by William Senior Nassau which states that human needs consist of basic needs (necessity), secondary (Decency), and tertiary needs (luxury). AlGhazali was also expressed about the main purpose of the application of sharia is a matter of religion or religion, life, thoughts, lineage, and wealth is concerned with economic problems.

According to Anas Mustafa Zarqa (1980), Imam Al-Ghazali was the first Muslim scholar formulated the concept of a social welfare function. In discussing human issues, including economic activity, Imam al-Ghazali always refers to the concept of benefit (welfare) as its central theme. He said the goal is to preserve beneficiary lies in the protection of Islamic religion (din), soul (nafs), intellect (aql), descendant (nasl) and property (mal).

So if we study the concept of welfare as those described in the thought of Al Ghazali, then we view 
the ideas and thoughts about the welfare which its include physical and non-physical aspects, so that it were broader than just the economic aspects alone, but also involved the welfare of humanity broadly. This implies that the notion of economic growth in the physical sense was further discussed by Al-Ghazali, because aspects of welfare in a broader senses already mentioned and discussed in his thoughts.

\section{Demand, Supply, Prices and Profit}

Imagine if the activity patterns rely on barter trade or economic life is too many rules governed. Probably not grow and the price distortions would be so great. That is why the idea of the necessity of trading activity is determined by the law of supply and demand, long before the advent of modern economic thinking-has been expressed by Islamic thinkers.

Imam al-Ghazali explicitly acknowledges mutuality in economic exchange that requires specialization and division of labor and resource areas. He realized that trading activity adds value to goods trade because they can make the goods reach at the right time and place. Driven by self-interest of people, were causing exchange intermediaries who seek to profit, that was traded. Further, he stated that trade is essential for the proper functioning properly progressive economy. Imam al Ghazali also mentions the need for a secure trade routes and safe. The State shall provide protection so that the market can expand and grow the economy.

One is the view of Abu Hamid al-Ghazali. Probably quite a surprise when he presents a detailed explanation of the role of trading activity and the emergence of market prices move according to the forces of demand and supply. Understandably, he was known as an expert in Sufism.

For al-Ghazali market is part of the "natural order". In detail, also describes how the evolution of the creation of the market. Al Ghazali stated: "Farmers can only live where agricultural equipment is not available, otherwise blacksmith and carpenter living in which there is no agricultural land. But naturally, they will meet their individual needs. carpenter may also need to eat, but farmers do not need such tools or otherwise. This situation raises a problem. Therefore, it naturally also people will be encouraged to provide storage of tools in one hand and a storage area results in line with the needs of each market forming. Farmers, carpenters and blacksmiths who can not immediately make exchanges also encouraged to go into this market. When the market was also not found people to barter, he will sell to traders at a relatively cheap price and then stored as inventory. Traders then sell with a profit rate. This applies to every item."

Imam Ghazali had also explained regional trade explicitly. Al Ghazali said: "Furthermore, these practices occur in different cities and countries. People travel to different places to get food tools and take it to another place. Economic affairs people eventually organized into cities where not all food needs. This condition in turn raises the need for transportation. Creating regional merchant class in society. and his motive of profit, of course. The merchants are working hard to meet the needs of others and make a profit and livelihood by others as well. (Ihya, III: 227).

Imam Ghazali Clearly awares of the difficulties of barter system, the need for specialization and division of labor according to regional and local resources. He also realized the importance of trade to provide added value to provide it at the time and place where needed. Al-Ghazali also introduced the theory of supply and demand: if the farmers do not get a buyer, he would sell it at a cheaper price, and the price can be lowered by increasing the number of goods in the market. Al Ghazali also introduced the elasticity of demand, he identifies the demand for food products is inelastic, because food is a basic necessity. Because the food trade high profit motive should be minimized, if you want to get high profit from trading, should look for items that are not a necessity.

Imam Ghazali and thinkers of his time when talking about prices are usually directly related it to profit. Profits had not been clearly linked to income and expenses. For Ghazali profit is the compensation of weary travel, business risk, and threat of personal safety of merchants (Ulumuddin Ihya, IV, 110). Although he did not agree with the excessive profit to be motivated traders, but according to Al-Ghazali, that profit ware the motivation of the traders. But for Al Ghazali real profit is a benefit in the hereafter (Ihya Ulumuddin, II :75-6, 84).

So that the growing trade activities running, with the motivation to make a profit, make greater economic activity in the quantity of goods and services that can be produced, of course this will make the economy grow and become increasingly extends.

\section{Taxes}

According to Imam al-Ghazali, if the condition of the State needs soldiers to guard and protect the 
territory from all kinds of threats, while the state treasury was not enough, the government reserves the right to collect taxes from the people who can afford. In this case, it requires that the State government was a credible government, the financial condition of the State is really empty, and this is just a special tax policy imposed on the condition, which is to meet the needs of the army alone.

Al Ghazali discussed the public finances by reviewing the two sides, which discussed the budget in terms of revenue and expenditure side or spending. He explained the various sources of incomes follow the Islamic rules that determine which is allowed revenue, such as zakat, waqf, shodaqoh of the Muslims, and the jizya from non-Muslims which have protection from the state, there is also revenue from the booty, and fai. So these income sources are not just following the needs and habits of society but must be obtained in which legal and lawful manner.

Al-Ghazali also contributed additional ideas in the application of tax that has been set out with a definite clear in Islamic rule, namely the rule set if necessary in the circumstances, for example to finance and maintain the public good, such as the need for additional financing of national defense, or the protection of the poor or neglected children, it is justified in keeping for the benefit of additional tax determined, by considering the ability to pay of the citizens and the effects on economic activity in general.

Al-Ghazali also talked about ideas and thoughts about the possibility of a loan made by the state, which the state requires financial resources to carry out its functions, such conduct public facilities financing, or financing for the armed forces and other public interests. Of course this will have an effect on the general welfare of society, for example in the procurement and provision of public facilities, then this will provide a positive multiplier effect to the activities of citizens and societies.

And other matters highlighted by Al-Ghazali is on the sides and aspects of expenditure made by the state, as part of balancing the public finances, the state's expenses and expenditures are discussed in more flexible and broadly covers the enforcement of justice, national security, community development more prosperous, which all the focus on how the state can perform its functions in accordance with the priority of interests to be achieved.
If we examine the ideas and thoughts of $\mathrm{Al}$ Ghazali above, then we viewed that in the discussion area of public finance, the focus of the Al Ghazali's goals are, how the role and function of the state as an institution that will give the benefit and welfare for the citizens and societies that could be achieved with the financial arrangements. This ideas are very similar to the welfare of economic thoughts in the contemporary ideas today.

\section{Ibnu Taymiyyah Economic Views}

Shaykh al-Islam Taqi ud-Din Abu'l-Abbas Ahmad Ibn al-Halim ibn Abd al-Salam Ibn Taymiyah al-Hanbali was born in , $661 \mathrm{AH}(1263 \mathrm{AC})$ in Haran, which is now in Eastern Turkey, near the border of northern Iraq.

His family had long been renowned for its learning, among his teachers, was Shams ud-Din Al-Maqdisi, first Hanbali Chief Justice of Syria following the reform of the judiciary by Baibars. The number of Ibn Taimiyah's teachers exceeds two hundred. Ibn Taimiyah was barely seventeen, when Qadi Al-Maqdisi authorized him to issue Fatwa (legal verdict). Qadi remembered with pride that it was he who had first permitted an intelligent and learned man like Ibn Taimiyah to give Fatwa. At the same age, he started delivering lectures. When he was thirty, he was offered the office of Chief Justice, but refused, as he could not persuade himself to follow the limitations imposed by the authorities.

Imam Ibn Taimiyah's education was essentially that of a Hanbali theologian and jurisconsult. But to his knowledge of early and classical Hanbalism, he added not only that of the other schools of jurisprudence but also that of other literature.He had an extensive knowledge of Quran, Sunnah, Greek philosophy, Islamic history, and religious books of others, as is evident from the variety of the books he wrote.

He elaborated a circumstantial analysis of the market mechanism ie. Do we need to regulate or deregulate the market?, with a theoretical insight unusual in his time (ayat not clear). His discourses on the welfare advantages and disadvantages of market regulation and deregulation, have an almost contemporary ring to them. Ibn Taymiyyah commenting on the power of supply and demand: "If desire for goods increases while its availability decreases, its price rises. On the other hand, if 
availability of the good increases and the desire for it decreases, the price comes down."

Ibn Taymiyyah has laid the basic concepts of Islamic economics that will be instrumental in driving growth and economic equality. Among the basic concepts are related to:

\section{Fair Prices}

The concept of a fair price has basically been contained in the teachings of Islam. Even if the use of the term has been around since the early presence of Islam, Ibn Taymiyyah seems to be the first to give special attention to the problem at a fair price. In discussing the issue price, he often used the two terms, namely compensation equivalent ('iwadh almitsl) and the price equal to (tsaman al-mitsl).

Compensation equivalent (iwadh al-mitsl) is used when examining legal ethics while in terms of price equal when reviewing aspects of the economy. According to the principle of equal compensation contained in the following cases: (i) when someone must be held accountable for endangering others or damaging property and profits; (ii) when a person has an obligation to repay the amount of goods or equivalent benefits or pay compensation to the injured part of others; (iii) when a person is asked to determine aqad damaged and covenants saheeh in an aberrant event in the life and property.

The same general principle applies to the payment of fees, compensation and other financial obligations. For example: (i) gifts given by the governor to the orphans, endowments and Muslims; (ii) compensation by a representative of the business agent for the payment of compensation; (iii) provision of wages by and or to business partners.

While the price equal to the price established by the market forces run free, ie encounter between the forces of demand and supply. So different from the concept of an equivalent compensation, the issue price equal appears when faced with the actual price, purchase and exchange of goods.

\section{Market Mechanisms}

Ibn Taymiyya's statement is seen in the following statement: "Rise and fall of prices is not always related to the tyranny of a person. Occasionally, the reason is the deficiency in production or decline in imports of goods demanded. So if you need an increase in the number of goods, while the ability to decline, prices will go up by itself. On the other hand, if the ability of the supply of goods increases and demand decreases, prices will fall. Scarcity and abundance are not necessarily caused by one's actions. It could be related to the cause that does not involve injustice. Or sometimes it could be caused injustice. Almighty God who created the will of the human heart."

The statement is a picture of what happened in those days, where the price increases caused by the injustice of the salespeople. That is manipulation by sellers pushing the market imperfections. Thus, according to Ibn Taymiyyah, for economic reasons for the rise and fall of prices and the role of market forces, should also be considered.

Supply changes in market forces, as well as demand, described as an increase or decrease in the availability of goods. He also mentions two sources of supply are local production and imports. What Ibn Taymiyya expressed actually shows what is currently known function of supply and demand, without specifying.

Ibn Taymiyya also mentioned, the price could rise due to decreased amount of goods available, or an increase in the population. Decrease the amount of goods equal to the decrease in supply, whereas the increase in population will result in increasing demand, thus raising prices due to reduced supply and increased population is a natural mechanism for God.

Ibn Taymiyya noted several factors that affect the demand and price: the desire of different people and changing the types of goods; the number of applicants; the level of demand for goods; parties exchange; and forms of payment instruments used in the sale and purchase.

\section{The Setting of The Price}

There are differences in prices will rise due to market forces and injustice or tyranny such as hoarding. Ibn Taymiyyah thus lays the foundation of the authority of government regulation on following issues, i.e., ownership of assets, money and monetary policy, sources of public revenue, public expenditure, and the role of the state in the economy.

Link with current view that law/enforcement/ regulation might affect the economic growth

\section{Ibn Khaldun Economic Views}

Weiss (1995) quotes the Ibn Khaldun's view on economic growth, as reported in Muqaddimah 2:27273: When civilization [population] increases, the 
available labor again increases. In turn, luxury again increases in correspondence with the increasing profit, and the customs and needs of luxury increase. Crafts are created to obtain luxury products. The value realized from them increases, and, as a result, profits are again multiplied in the town. Production there is thriving even more than before. And so it goes with the second and third increase. All the additional labor serves luxury and wealth, in contrast to the original labor that served the necessity of life.

\section{Introduction}

One of the most prominent Muslim intellectuals and most thinking about economics was Ibn Khaldun. (1332-1406). Ibn Khaldun is a Muslim scientist who has a lot of thought in various fields, such as economics, politics and culture. One of Ibn Khaldun's ideas that very prominent and very important to discuss which is his thoughts on the economy. This paper will discuss the economic thought of Ibn Khaldun by analytical methods, descriptive and comparative. Ibn Khaldun's discussion of the importance of thinking about the economy because the thoughts of great significance for the future development of Islamic Economics. In addition, this paper also wants to point out that Ibn Khaldun is the father and economists who preceded Adam Smith, Ricardo and other European economists.

Ibn Khaldun is the foremost intellectual giants of the world. He not only sociologists but also father of Economics science, because many his economic theories that go beyond Adam Smith and Ricardo. That is, he was more than three centuries preceding the modern Western thinkers. Muhammad Hilmi Murad has written a paper entitled Abul Iqtishad: Ibn Khaldun. That is Father of Economics: Ibn Khaldun. In the text of Ibn Khaldun demonstrated scientifically as the originator of the first empirical economics. This paper according to Zainab Al-Khudairi, delivered at the Symposium on Ibn Khaldun in Egypt 1978.

Before Ibn Khaldun, economic studies in the Western world were still normative, sometimes studied from a legal perspective, from the perspective of moral philosophy and unisex. The works of the economy by the West Scientist, such as Greek scientist and unscientific patterned Scholastic era, medieval thinkers such as economic studies incorporate the moral and legal studies.
While Ibn Khaldun assess the economic problem of society and the state empirically. He describes the phenomenon in an actual economy. Nejatullah Muhammad Ash-Shiddiqy, write down the key points of the study material Ibn Khaldun on the economy: "Ibn Khaldun has a wide range of discussions on economics Including the subject of value, division of labor, the price system, the law of supply and demand, consumption and production, money, capital formation, population growth, Macroeconomics of taxation and public expenditure, trade cycles, agricultural, industry and trade, property and prosperity, etc. He discussses the various stages pass through roomates societies progress in economics. We also get the basic idea embodied in the backwardsloping supply curve of labor."

Along with his writing, Shiddiqy Boulokia, at Ibn Khaldun: A Fourteenth Century Economist, says: "Ibnu Khaldun discovered a great number of fundamental economic notions a few centuries before their official births. He discovered the virtue and the necessity of a division of labor before Smith and the principle of labor value before Ricardo. He elaborated a theory of population before Malthus and insisted on the role of the state in the economy before Keynes. But much more than that, Ibnu Khaldun used these concepts to build a coherent dynamic system in which the economic mechanism inexorably led economic activity to long term fluctuation

Due to the large contribution of Ibn Khaldun in economic thinking, then Boulakia said, "It can be justified if we refer to Ibn Khaldun as a Father of economics. "Siddiqi also concluded that Ibnu Khaldun has rightly been hailed as the greatest economist of Islam.

Accordingly, it is not surprising that many leading scientists are researching and discussing contemporary Ibn Khaldun's ideas, particularly in the economic field. Ezzat doctoral dissertation on Ibn Khaldun wrote titled Production, Distribution and Exchange in Khaldun's Writing and Nasha't wrote "al-Fikr al-iqtisadi $f i$ muqaddimat Ibn Khaldun (Economic Though in the Prolegomena of Ibn Khaldun). In addition we have donations galore study of Ibn Khaldun. This shows the greatness and pioneering Ibn Khaldun as a prominent intellectual who has formulated brilliant thinking about the economy. Rosenthal has written works such as Ibn Khaldun The Muqaddimah: An Introduction 
to History, Spengler wrote the book Economic Thought of Islam: Ibn Khaldun, Boulakia wrote, Ibn Khaldun: A Fourteenth Century Economist, Ahmad Ali writes Economics of Ibn Khaldun-A Selection, Ibn al Sabil wrote ishtirakiyat fi'l Islami Islam, Abdul Qadir wrote: Ibn Khaldun to ma'ashi khayalat ", (Economic Views of Ibn Khaldun), Rifa'at par wrote: Ibn Khaldun Ma'ashiyat to Khalayat" (Ibn Khaldun's Views on Economics) Somogyi wrote the book Economic Theory in the Classical Arabic Literature iqtisad al-Tahawi al-islami madhhaban nizaman wa wa Dirasah muqaranh. (Islamic Economics-a School of Thought and a System, a Comparative Study), TB Irving wrote Ibn Khaldun on Agriculture, Abdul Sattar wrote a book: Ibn Khaldun's Contribution to Economic Thought" in: Contemporary Aspects of Economic and Social Thinking in Islam.

Spengler(1964)comparesand contrasting theories of Ibn Khaldun's cycle of civilization with Hick theory regarding trade cycle. Abdul Sattar (1976) said that the theory of economic development the stages through from Ibn Khaldun. We get the macroeconomic trade "that in every city there is a balance between revenue (income) and expenses (expenditure) ... and when both (revenue and expenditure) is growing, meaning that the city develops. "Shiddiqy (1982) noted, Ibn Khaldun also discussed the importance of the demand side (demand), especially in dealing with state spending and the business slump maintain economic development. T.B. Irving (1955) also noted, that according to Ibn Khaldun, "tax" in terms of the return has shrunk, and inject finance is necessary to keep the business running smoothly."

Abdul Qadir (1942) noted that labor occupies a central position in the theory of Ibn Khaldun, Abdul Sattar (1976) said the labor theory of value comes from Ibn Khaldun, Somagyi (1965) correctly argued that Ibn Khaldun preceded Adam Smith in several respects. Abdul Qadir considered Ibn Khaldun as a pioneer of the merkantilist, because of his views on the importance of the position in the trade of gold and silver. He highlights the emphasis that is placed upon Ibn Khaldun to economic factors in the interpretation of history and attempt to link economic development with political stability, Ibn al-Sabil considers Ibn Khaldun as a pioneer far ahead of Karl Marx, Proudhon, and Engels, in his book, Ibn Khaldun's views on poverty and its causes.
Rifa'at (1937 ) also shows the historical fact that Ibn Khaldun has preceded analyzes of Western scholars who came later, such as the theory of utility (benefit). Furthermore, Ibn Khaldun discusses the functions of money. He said the money has two functions, namely as a measure (instrument) exchange (standard of exchange) and as a store of value (store of value).

Rifa't compares the theories of Ibn Khaldun and the Malthusian theory of population. Here Rifat found a number of similarities between the two, although did not mention about Ibn Khaldun preventive supervision.

In his discussion of the fundamental Ibn Khaldun, Tahawi (1974 ) explain how population growth and economic development are closely linked to each other in the model. Ibn Khaldun also warned of state intervention in the economy and believe that the creation of the free market better ensure equitable distribution or reasonable. Furthermore Tahawi summarizes the views Ibn Khaldun on theory of price by the law of demand (demand) and supply (supply), the money, the value and use as well as the principles on taxation and government spending.

In his discussion of the opinion of Ibn Khaldun, Tahawi explain how population growth and economic development are closely linked to each other in the model. Ibn Khaldun also warned of state intervention in the economy and believe that the creation of the free market better ensure equitable distribution / reasonable. Tahawi further summarizes the views of Ibn Khaldun on the determination of prices by the law of demand (demand) and supply (supply), the money, the value and use as well as the principles of taxation and government spending.

Boulakia explained that the emphasis of Ibn Khaldun on the importance of civil society organizations in the production, which is the main factor of human labor. Then comes the role of the division of labor is more internationally based on the skills of the population in the area instead of its natural resources. Ibn Khaldun's theory contains the beginning of the theory of international trade, accompanied by an analysis of the exchange terms between rich countries to poor countries, about the tendency to import and export activities around the globe, on the effects of the economic infrastructure of the development and importance of intellectual capital in the growth process. " 
Based on the above explanation which is based on a scientific analysis of leading scientists, it can be concluded and confirmed that Ibn Khaldun is the father of the world economy, it is not the slightest doubt. Ibn Khaldun's thoughts on the economy, as noted above in summary, will elaborates in the following discussion.

\section{Ibn Khaldun's Circle of Equity}

Among the ideas of Ibn Kaldun very important and unique are his thoughts on the circle of societal welfare. In Ibn Khaldun's Circle of societal welfare connects with some variables that relate to and influence each other in a forward or rewind of

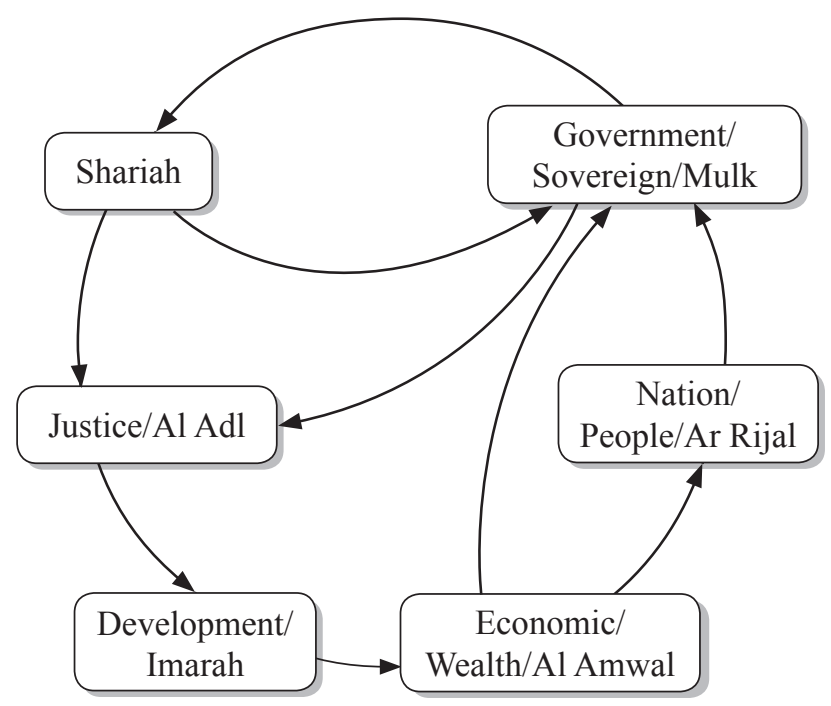

The image is read as follows:

Government $(\mathrm{G})$ cannot be realized except by

implementation of Sharia (S)

Sharia $(\mathrm{S})$ cannot be realized unless the government/ authorities $(\mathrm{G})$

Government $(G)$ cannot be obtained except by a public authority $(\mathrm{N})$

Government $\mathrm{G}$ ) does not happen without a strong economy $(\mathrm{W})$ is tough

Public (N) cannot be realized unless the economic/wealth (W)

Wealth (W) cannot be obtained except by the construction of (D)

Development (D) cannot be achieved except through equity $(\mathrm{J})$

Ruler / government $(\mathrm{G})$ is responsible for justice $(\mathrm{J})$ Justice $(\mathrm{J})$ is Mizan which will be evaluated by God, (Muqaddimah (M): 39;Rosenthal's translation (R): vol. 1, 80).5 civilization. Ibn Khaldun's thought in this regard can be seen below:

Ibn Khaldun suggests a combined formulation and relationship variables are a prerequisite to realize a state $(\mathrm{G})$. Variables are Shariah $(\mathrm{S})$, the $(\mathrm{N})$, wealth (W), development (D) and justice (J).

All of these variables work in a dynamic circle interdependent and interrelated. Each variable will be the factors that determine the progress or decline of civilization and its collapse. The uniqueness of the concept of Ibn Khaldun is no assumption is considered fixed (cateris paribus) as taught in conventional economics today. Since there is no fixed variable (constant), a variable can be a trigger, while the other variables can react or not in the same direction. Since the failure of any one variable is automatically spread and have an impact back, but it can be fixed. When these variables were damaged beyond repair, it could change the direction back towards progress. Conversely, if it can not be fixed, then the direction of rotation of the circle against the clock, that is, toward a setback. However, when other variables react to the same triggers a reaction, then failure will take a long time to identify the cause and effect.

Relationship variables above can be illustrated as follows, If each variable were combined, functional relationships embodied in this formula:

$\mathrm{G}=\mathrm{f}(\mathrm{S}, \mathrm{N}, \mathrm{W}, \mathrm{D}, \mathrm{J})$

$\mathrm{G}$ is a function of the variables $(\mathrm{S}, \mathrm{N}, \mathrm{W}, \mathrm{D}, \mathrm{J})$. $G$ placed as the dependent variable, because the $G$ in this case is the continuity of of civilization, the triumph or decline / collapse, influenced by five variables. It is simple to read that ruling $(G)$ in charge of and responsible to implement Shariah (S), because without Shariah, the $(\mathrm{N})$ will be chaotic, the country will collapse. States should also ensure the rights of society and the welfare of society is responsible (N) to the prosperous / prosperous (W), through the construction of (D) and justice (J). When a variable is not met, then the rule becomes a matter of time to collapse.

\section{Division Of Labor}

According to Ibn Khaldun, as he advances to the fifth chapter of al-Muqaddimah, there are three main categories of work: agriculture, trade and various other activities. The simplest means of production is 
agricultural. This work, according to Ibn Khaldun, requiring no knowledge and he is a "livelihood of people who do not have and the people of the village". Therefore, this work is rarely done by the people of the city and the rich. Here it seems that Ibn Khaldun put agriculture on the job rank slightly lower than the work of professional city people.

Ibn Khaldun's assessments due at least three reasons. First, it does not require extensive knowledge and deep, because anyone can become a farmer without agricultural school. This analysis suggested it because at that time the community was simple and there is no faculty of agriculture as it is now. Second, when viewed in terms of the amount of income, farmers generally earn lower than city people. Third, farmers are required to pay taxes.

According to Ibn Khaldun people who pay taxes are the ones who are weak, because powerful people did not want to pay taxes. The third reason is also different from the conditional nature of the modern condition today.

\section{Trade}

Furthermore, Ibn Khaldun explains that farmers produce more crops than they need. Therefore they exchange their excess production to other products they need. From this arises trade (tijarah). So, this trade work chronologically arises after the agricultural production.

Furthermore, Ibn Khaldun says that: "the profit obtained traders will trade small in small capital. But when big capital so thin profit would be a big advantage."

Ibn Khaldun also criticized the officials and authorities who trade. It seems intended by Ibn Khaldun that the authorities can act fairly towards the traders. This point becomes important applied in the present, in order to avoid a monopoly by ruling that employers project.

In the discussion and study of the trade role, Ibn Khaldun also expanded economic discussion involving external factors, namely the existence of inter-regional trade and even international trade. This activity was done in order to market their excess domestic production which is not absorbed by the domestic market, or because of the value and better prices in markets outside of the country to obtain higher level of profit.
Economic activity that extends up out the country would generate additional revenue for the domestic, or in other words to get additional income, which in turn will make domestic economic activity to be greater in the production of goods and services. This will make the economy has greater capacity and also make the country's economy and society to grow and develop.

\section{Industry}

Ibn Khaldun classifies industries into two, first, the industry that meets human needs, both the primary and the secondary, and second industries specially engage in the ideas / thoughts, such as "screenwriting books, bookbinding, the profession as a singer, preparation of poetry, teaching science, and so forth. Ibn Khaldun also includes professional soldiers in the latter classification.

The division of labor based on the division of society into two, namely rural and urban communities. Villagers are engaged in agriculture and animal husbandry. While the people of the city are engaged in trade and industry. Opinion Ibn Khaldun mentioned above is almost in line with the opinion put forward by Marx in his work The German Ideology. Marx said: "The division of labor in a nation, will first make the separation of industrial employment and trade of agricultural labor, and also makes the separation of the village from the city."

The similarity is also found in other texts in the works of Marx. Indeed, sometimes there are similarities between Ibn Khladun and Marx, in particular with respect to the phase of organizing the state. The link between industry and the division of labor itself also acknowledged Marx, among others, as set forth in his misere de la Philosophie, lies the greatness of Ibn Khaldun, as he has formulated a division of labor thought centuries before Western thinkers such as Karl Marx formulated.

\section{Price Theory and Law of Supply and Demand}

Ibn Khaldun was already formulated a theory of prices long before the modern Western economists define it. As mentioned at the beginning of Ibn Khaldun have preceded Adam Smith, Keyneys, Ricardo and Malthus. This is an undeniable historical fact. Ibn Khaldun, in his book Al-Muqaddimah write a chapter specifically the chapter entitled "Prices 
in the City": "When a city has a highly developed, abundant civilization and is full of luxuries, there is a very large demand for those conveniences and for having as many of them as a person can expect in view of his situation. This results in a very great shortage of such things. Many will bit for them, but they will be in short supply. They will be needed for many purposes and prosperous people used to luxuries will pay exorbitant prices for them, because they needed them more than others. Thus, as one can see, prices some to be high ".

Here Ibn Khaldun has empirically analyzed the theory of supply and demand in the community. In the above sentence Ibn Khaldun formulated explicitly turn on the law of supply and relation to the price. He said if a city is growing rapidly, progress and densely populated, the abundant supplies of basic foodstuffs. This could mean increasing the supply of goods that result in cheapening the price of basic goods. This is the meaning of writings of Ibn Khaldun: "When a rapidly growing city, densely populated, then the prices of basic needs (such as food) to be cheap".

Analysis of supply and demand of Ibn Khaldun was in modern economics, theorized as the increase in disposable income of urban residents. Rising disposible income (excess income) to raise marginal propersity to consume (marginal tendency to consume) to luxury goods of every resident of the city. This creates a new demand or an increase in demand for luxury goods. As a result, prices of luxury goods will also rise. The existence of these trends due to the disposable income of the population along with the development of the city.

Furthermore, Ibn Khaldun says: "Foodstuffs in small cities that have few inhabitants are few, because they have a small (supply) of labor and because, in view of the small size of the city, the people fear food shortages. Therefore they hold on to (the food) that comes into their hands and store it. It thus becomes something precious to them and those who want to buy it have to pay higher prices. They also have no demand for conveniences, because the inhabitants are few and their condition is weak. Little business is done by them, and the price there, consequently become particularly low."

Furthermore, Ibn Khaldun also discusses the profit (riba). According reasonable profit will encourage the growth of trade. Low profits will make a sluggish trade as traders lose motivation. Conversely, if traders take advantage of a very high, it will also cause lethargy trading as weakening consumer demand. It should also be noted that of the thought of Ibn Khaldun was a detailed and explicit explanation of the elements of the competition. Furthermore, Ibn Khaldun observed phenomenon of high and low prices in different countries, without asking any concept of price control policy.

This is the difference between Ibn Khaldun and Ibn Taymiyyah. Ibn Khaldun is more focused on the actual explanation of the phenomena that occur, while Ibn Taymiyya more focused on policy solutions to address the phenomenon.

In reviewing the demand problem, Ibn Khaldun discusses the determinants that raise and lower demand. According to him, there are at least five factors, 1. Price, 2. Revenue, 3. The population, 4. Habits of the people and 5. Construction of the general welfare.

While in the context of supply, its determinants are six, i.e., price, demand, profit, labor, safety, and welfare. Ibn Khaldun theorized that an increase in supply will lower prices. Conversely, if there is a decrease in supply will raise prices.

Ibn Khaldun as described by Umer Chapra stated that prices that are too low will hurt artisans and merchants, so that would push them out of the market, on the contrary, high prices would harm consumers. Therefore, the prices are moderate between the two extremes is the desired equilibrium price point, because it does not only provide the level of benefits to be socially accepted by merchants, but will also clean up the market by pushing sales and in turn will lead to profits and great prosperity.

On the other hand, low prices obviously still wants to basic needs goods, as this will ease the burden on the poor who are the majority of the population. From Ibn Khaldun's thought, it seems that he really wants the creation of a stable price to the cost (cost) of living is relatively low. Increased demand greatly affects supply. This condition will raise the prices of goods. This reality has been extensively described by Ibn Khaldun, as has been stated above in summary.

\section{Wage Workers}

Ibn Khaldun also discussed labor problems in the economy. He calls the terminology shina'ah term labor (factory work), as she wrote in the Muqaddimah: "Work at the plant / company is practical abilities 
associated with expertise. It says practical skills for work-related physical material, in which a worker works directly senses. In the modern economy, shina'ah terminology is known as employment. People who do that are called employee or labor."

Ibn Khaldun was the first scientist in history to give a detailed explanation of the theory of labor value. According to him, labor is the source of value. Important to note that Ibn Khaldun never called value workers with the term "theory". Nevertheless, a detailed explanation of the labor of Ibn Khaldun described in Chapter IV of the book Al-Muqaddimah.

Ibn Khaldun's thoughts on labor is further developed by David Hume in his Political Discourse published in 1752 by saying, "Everyone on earth is produced by labor." This statement further quoted Adam Smith in the footnote, "Everything is purchased with cash or goods produced by the workers." Money or goods to save us. We value the quantity of labor exchange in accordance with the time required to produce a quantity. Thus, the actual value of a commodity is not to be used or consumed alone, but in exchange for other commodities are proportional to the quantity of labor. Labor is thus a measure of the exchange value of all commodities.

If this paragraph were published in 1776 is considered as the thought of Adam Smith, it turns out these ideas have been put forward by Ibn Khaldun over three centuries before Adam Smith, as the description below: crafts and labor also are expensive in cities with an abundant civilization. There are three reasons for this: First, they are much needed, because of the place luxury occopies in the city on account of its large population. Second, industrial workers place a high value on their services and employment (since they do not to work) since live is easy in a town because of the abundance of food there.

Third, the number of people with money to waste is great, and these people have money needs for which they have to employ the services of others and have to use many workers and their skills. Therefore they pay more for (the services of) workers than their labor is (originally considered) worth, because there is competition for (the services) and the wish to have exclusive use of them. Thus, workers craftsmen and professional people become arrogant, their labor becomes expensive, and the expenditure of the inhabitants of the city for this thing, increase.
The most decisive factor, urgent and valuable (qimah) in the economy according to Ibn Khaldun is working laborers who have the skills are termed shina'ah. In this regard Ibn Khaldun said in an article with the title al-Muqaddimah "Reality sustenance, income and Explanation On Both And that revenue is Value of Human Work".

It is interesting that the same thing Marx raised about 4 centuries after Ibn Khaldun. Marx said: "The quantity of work to produce something alone that determines the quantity of value of production (output)".

They have been expressed also by Lenin. Marx is not the person who first argued about the value of modern times. It has previously been suggested an economist affiliated, William who argued that material wealth is work. After that comes the first chapter Ricardo his Principles of Political Economy and Taxation states the following: "The value of goods lies in the relative quantity of labor, the quantity needed to produce it, and not with the wage information available in this work."

While Adam Smith, in his Wealth of Nations, in describing the most common form of the law of value among others, said the following: "Work is the real measure of the value of reciprocity."

But apparently before the thinkers in the emerging, there has been a Muslim thinker concerned with economic reality as well as paying attention to analyzing it, and eventually he understands the laws that control the fact, and put forward the theory of value. Indeed, he did not spell out the laws in detail in several chapters, but even so he has put the principles in a clear and concise.

According to Ibn Khaldun's work is an important factor in creating progress and cultural splendor. When Aristotle despised handwork, otherwise Ibn Khaldun saw as a sign of cultural progress. Thus Ibn Khaldun appreciates the work and economic impact. It also emphasizes the social function and morale. Roger Garaudy explains in his study of Ibn Khaldun, Ibn Khaldun's theory of value that is based on the work and he was doing so prior to the European economists in the eighteenth century. Muhammad 'Ali Nasy'at appropriately commented to Ibn Khaldun in this issue: "Ibn Khaldun should be included in the ranks of the best writers on economic issues, because of his deep understanding on the essence of the economic problems of the most complex, of which the theory of value " 


\section{Factors of Production}

Factors of production according to Ibn Khaldun, there are three, namely nature, employment, and capital. But the opinions of Ibn Khaldun on the three factors are scattered in al-Muqaddimah. First of all, as a natural resource which provides the human form of the material can be used sometimes directly and sometimes after being processed. Ibn Khaldun said in his description of the impact of the production of nature: thus nature is the principle of all forms of production.

Being the second factor, namely the work, it has been described earlier in the discussion of the theory of value. But here be added that this factor is the main factor that exceeds the two other factors. Factor of this work has the advantage of a positive pattern. And this is a factor that always present in all forms of production, even natural products can not be obtained unless with work. At the time of Ibn Khaldun's own, work ahead of other production factors, as well as this factor apart from the capital. For when that capital owners are also workers.

Ibn Khaldun does not separate between capital factor by doing work such as the one conducted by economists today. As is known separation between capital and labor due to the impact of the industrial revolution and the emergence of the capitalists. Therefore it is not strange that Ibn Khaldun summarizes both factors.

According to Sobhi Mahmassani, Ibn Khaldun did not reveal the need for capital except in his capacity as one of the means of production. Or in other words, as the wealth and capital stock in the production process in addition to labor and natural factors. Ibn Khaldun did not much discuss the possible role of the owners of capital. In fact, he argues that the accumulation of large price will bring harm upon the owner of the authorities and officials, as where the words of Ibn Khaldun in an article titled "Concentration of non Mobile Assets and Land Estates: Advantages and Vices".

\section{Their Contributions to Economic Growth Theory}

\section{Money in Growth Theory}

Thoughts on the development or growth of Al Ghazali that economic growth and equity, is constructed with some other basic ideas, namely, previously, he discusses the fundamental issues about money as a component that plays a role in the economy, especially in the function as a medium of exchange between the producers of goods and services to the users of goods and services, , Or in other words that the interaction between producers as producers of goods and the bidder of goods to consumers as users of the goods or the demander of goods and services to be performed by the media they consume through a medium of exchange in the form of money.

That is one thing that a detailed discussion of the underlying and fundamental thought of $\mathrm{Al}$ Ghazali. This thought was followed by Ibn Taymiyah its analysis by addressing more focused on aspects of money. Then Al Ghazali continued discussion regarding the interaction between the strength of the market from manufacturers that produce goods and services represented by the supply side and the strength of consumers in asking for the items to be consumed as represented by the demand side, $\mathrm{Al}$ Ghazali see that this interaction is something that is natural means that the interaction of market forces are the supply side and the demand side will work under conditions where the power relying to a lot and lack of the goods and services produced and requested, means he gives emphasis to the things that free markets must be in pristine condition of stress or disorders that cause irregularities in the normal operation of the market, so he explains his analysis in the aspect of the formation of a fair balance of the market. This analysis is then discussed again by extending and view the other aspects of the market and the price equilibrium that is formed through the interaction of demand and supply by Ibn Taymiyah, he underlined the balance problems that is formed the market from the aspects of feasibility and fairness.

\section{Market Mechanism}

Thoughts about the market and its mechanism then becomes underlying case when Ibn Khaldun discusses his ideas regarding the role of government in maintaining the sustainability of natural markets, and how the role of government in maintaining public policy through taxation. Furthermore, Al-Ghazali provide opinion and analysis in the development of economic society by further discuss the trade practices between regions or within certain limits to international trade, he argues that the region's trade is due to the profit motive of the traders who look at the need for goods by consumers in a region that 
can not be satisfied by its local production, meaning that $\mathrm{Al}$ Ghazali look at the inter-regional trade is an extension of the practice in the discussion of the theory of supply and demand in the market mechanisms that have previously been discussed.

More profound, he saw that a gap in demand and supply of goods and services in the local area which is then filled with the fulfillment of other regions through trade between regions are a consequence of differences in the type and amount of goods that can be produced. This is a consequence of the division of labor and the perpetuation of the division of labor and specialization of labor in the economy and other areas. This thought explains that Al-Ghazali has been connecting how the production of goods produced and distributed is a consequence of the division of labor and specialization remains the work, or in other words he has linked the theory of demand and supply which occurs with the market mechanism and subsequently connected him to the regional trade / international and linking it with the concept of money especially as a medium of exchange and measuring instruments values and the role of government in the economy in order to keep the course running in natural conditions without the negative distortion that causes the interests and welfare and prosperity can be achieved.

From the description of Al Ghazali's economic thought, it can be seen that he had spoken on aspects of how the economy can be set in the Islamic social welfare function provides the base for the basic values of Islam (and Islamic monotheism) and how they can be run in the framework of the economic mechanisms that follow natural law (sunnatulloh) which can be described objectively. It is explaining that he has contributed thoughts on how the economy should grow by looking at the interaction of various factors and conditions as described previously.

Ibn Taymiyyah as the next generation of scholars of the period of Al-Ghazali contributed ideas with expand the discussion about the concept of money in relation to money as a medium of transaction in the distribution of goods and services produced by the producer to the consumer as their consumption needs. Then he connects the concept of money related to the amount of goods available in the economy, in which he directs the idea that the amount of money as a payment / transaction of goods and services produced must necessarily be in balance so as not to cause problems in the economy in the form of inflation that indicates the amount of money as a medium payments / transactions much more than the amount of goods and services produced or deflation problems that indicate the opposite.

Furthermore, he discusses more depth of interaction between market power on the demand side and the supply side representing the interests of consumers and the interests of producers with simultaneous dynamic analysis and also look at factors driving the supply side of the aspects of production and technology / efficiency, and he also look at that supply was with look at aspects of domestic and import through international trade, while on the demand side he discussed factors that influence the demand for tastes and incomes.

He underlined the passage must be fair market mechanism resulting fair compensation / equal and fair price, and explain the possible distortions in the market caused by the destructive actions of fair market mechanism. His idea was to explain that form the structure of the market that must be to get work done is a perfectly competitive market in which the role of government is to keep the market mechanism is fair and equal.

His idea was slightly different from the Al Ghazali relatively reject government interference in the market, due to Al-Ghazali on the assumptions underlying the market is run fairly, while Ibn Taymiyyah saw the possibility of market mechanisms do not work out as it should because of the distortion. Although it looks like there is a difference between the two, namely Al Ghazali and Ibn Taymiyyah, but it actually looks the same idea and the tangle of continuous discussions between the two with deeper and more comprehensive.

In his contributions to the concept of money, then Ibn Taymiyyah discusses in greater depth and broader aspects of the circulation of money in the broader sense, namely the phenomenon of the emergence of a form of payment other than the form of precious metals gold and silver. Ideas and thoughts of Ibn Taymiyyah was also may be an interwoven and the further development of the previous discussion started by Al Ghazali about the concept of money, with a more in-depth discussion and wider on the possible impact in the economy. His idea was subsequently affect the conventional Western economic thinkers Thomas Gresham of good money being replaced with bad 
money. As well as he also discusses the relationship of money with the amount of goods traded and its relationship with intrinstik and nominal values.

From the description of the thought of $\mathrm{Ibn}$ Taymiyyah, it may be concluded that he saw the economic development aspects of demand and supply of goods and services on the market that run fairly, is follow mechanism of supply and demand forces in the market structure that produces efficient and fair compensation and fair price and equivalents, which involves the monetary sector in this regard money as a good transaction in the sense as a means of transactions and in the distribution of goods through domestic and international trade in which the government goes on the market and keep the economy running order fair, the government also is active in order to encourage public spending that drive demand in a broader scope and encourage that the government was able to obtain results through tax revenues from a growing economy. If we look further, we see that Ibn Taymiyyah has integrated discussions on economic development by looking at aspects of the real economy and monetary sectors, and include domestic economic interaction with the international/overseas/regional, and incorporate the role of government in the economy, so economic growth is expected to grow steadily and rapidly.

Thought of Ibn Khaldun in the economy more comprehensive look because he also mengintegrasian non-economic factors such as political, social, cultural, psychological analysis that becomes a more thorough economic thought, and he even analyze further the progress of civilization of a nation.

Meanwhile his economic thought, may be arranged in the idea of money or the concept of money as a medium of transaction of goods and services produced and distributed between the seller/manufacturer with buyer/consumer, as well as measuring the value of goods and services. In terms of measuring value, he attributed the analysis of goods and services produced as well as the accumulation of capital or wealth. He argued that the price of gold and silver as the standard for money must necessarily be have a constant price in order to create stability in the measurement value, while other prices may change depending on the forces of supply and demand, so the balance that occurs in the market was a consequence of the natural movement of the market mechanism.

On the other hand, Ibn Khaldun gives the possibility of the use of standard currency to be backed by gold as a solution in the future if the economy is experiencing rapid growth. Therefore he argues that the State or the public wealth is determined by the amount of production and a positive balance of payments.

His idea was linked the concept of money with the production concept and the concept of trade both domestic and regional/international.

Furthermore, Ibn Khaldun describes economic activity in relation to the market price mechanism, in which he argues that market prices are supposed to create an acceptable price by the manufacturer because it provides incentives for an efficient production, while on the part of consumers is a reasonable price for consumers could be achieved by on the level of their consumption, so that interference or state intervention is not necessary because the market works naturally and can be accepted by economic actors.

Furthermore, Ibn Khaldun explains the concept of supply in the market along with the factors that influence it, and relate it to the concept of production or production theory, and on the other hand he also explains the concepts and theory of demand and its influencing factors, and relate it to the concept of consumption.

\section{Labour}

In explaining the theory of production, he further analyze the factors labor and the role of labor in the economy at the macro level, in which he explains that in undertaking the production of produce goods that people cooperate and do the division of labor and specialization of labor, so that will achieve a greater level of production because the work productivity of the workforce would be optimal, then he deeply analyze the value of labor in producing goods that value would be income for the labor itself. Opinions of Ibn Khaldun was later also used and described again by Adam Smith in the theory of division of labor.

Ibn Khaldun describes the distribution of income to gross income and income categories for a living, he also analyzes how revenue might be somewhere different than anywhere else or even for a job / profession that rely on the same standard of living of the progress and prosperity of the city or community in the area.

One factor that affects the motion of economic growth is the role of the state, especially in relation to State expenditure will be additional demand for goods and services that would boost production even more, so that economic development would be encouraged either through acceleration or multiplier effects. 


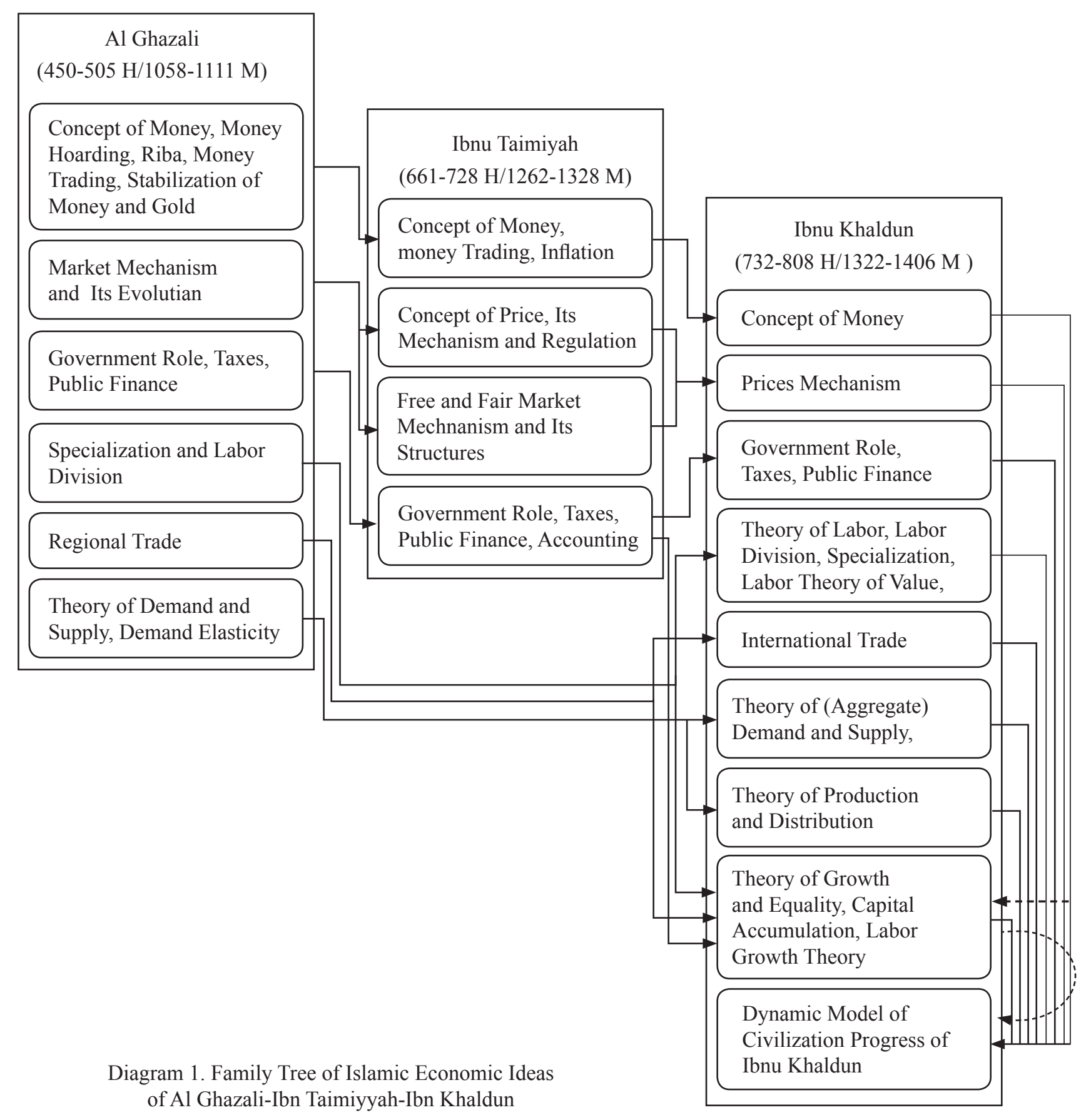

State spending is of course closely related to the income of such State income taxes, so Ibn Khaldun also contributed their thoughts in analyzing the role of taxation in the development and economic growth, he gave a sharp analysis of taxes to provide optimal drive to urge manufacturers perform encouragement production of both psychologically and economically, in order to obtain the optimal amount of taxes criteria that feasible in the economy. This opinion is then used as the basis for the description of Arthur Laffer.

On the domestic economic activity, we see that Ibn Khaldun linked with external economic activity in this case through international trade, in which he argues that regional trade/international encourage increased production of domestic goods when domestic consumption is smaller than their products, so most excess production will be distributed overseas through international trade activity, with the prices prevailing in the international market, which in turn will generate income as income for domestic 
producers. Increasing domestic production is a consequence of the increase in labor productivity due to the division of labor and specialization in work. Of this is seen in the thought of Ibn Khaldun aspects of production and distribution and how it relates with activities of the international economy through trade, or in other words he tried to relate the analysis of the internal economy with external economies.

In the analysis of economic growth and equity are more clear and deep, Ibn Khaldun noticed that important factor is how the accumulation of capital and labor growth become an engine. Capital in his thoughts rather refers to the artificial production factor, which may be capital money, a factor that people make investments, or capital goods can be profitable when done trading activity, or in other words he gives more definition to the capital to function not to shape, so the money in his view might not be an asset if it is not managed in the production process that produces goods and services, which in turn provide added value or profit.

\section{CONCLUSIONS}

From the above discussion, it can be view that the thoughts and ideas of the classical Islamic scholars in the fields of economics and economic growth have relevance and interconnectedness with each other, so it can be concluded that the thoughts and ideas they provide color and direction of development economics in future. Then the similarity of their ideas give a more comprehensive understanding with some emphasis on some aspects of his ideas. Their thoughts and ideas about the economic themes that subsequently form a thought in economic growth, which means that their thinking constitutes the frame and maps of how the study of the growth of an economy should be assessed. This provides a future direction that the discussion of economic growth should be discussed and studied by involving economic aspects and themes in a more comprehensive way.

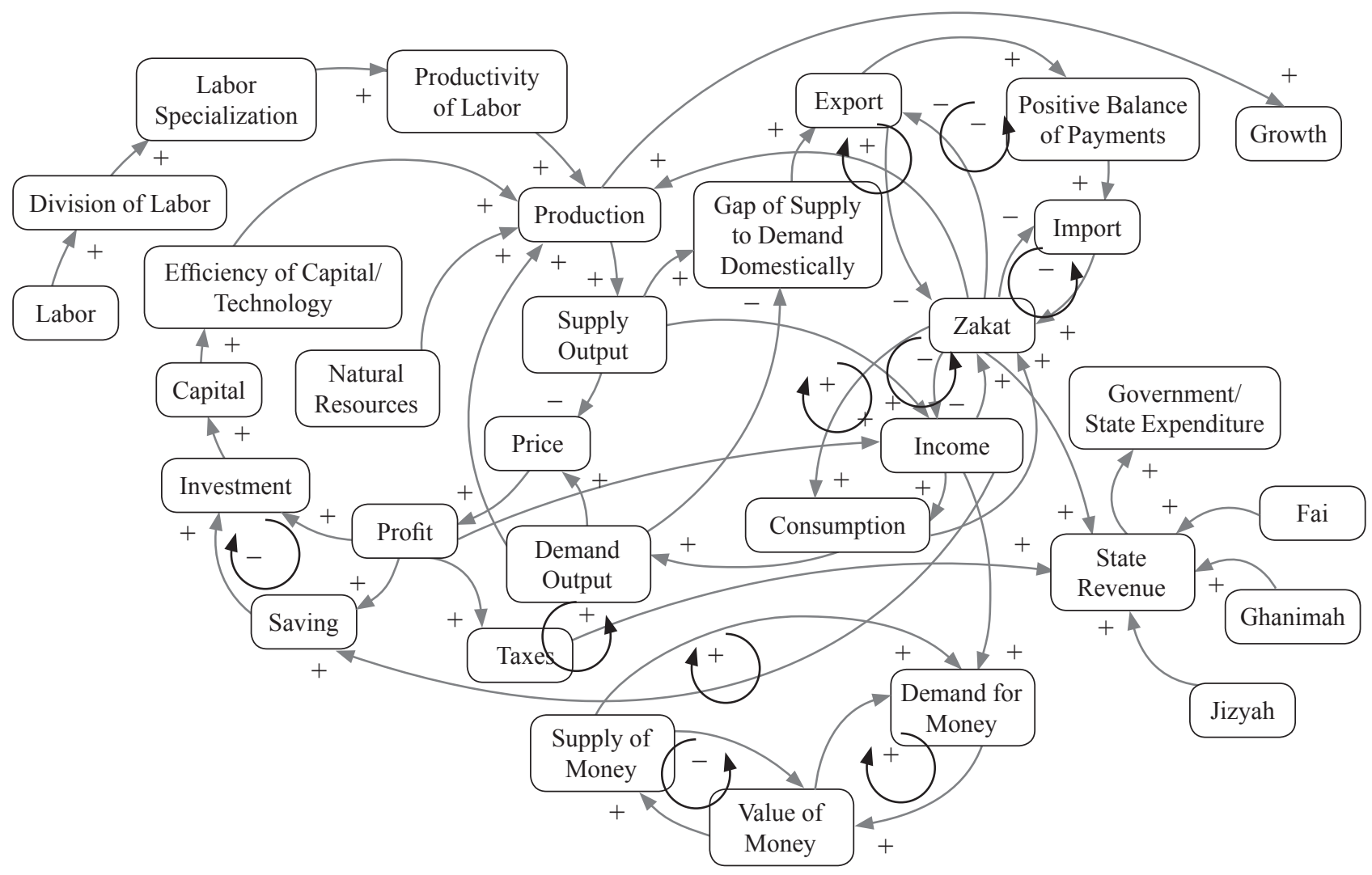

Diagram 2. Al Ghazali’s View of Economic Growth 


\section{REFERENCES}

Abdel-Hamid, T. K., \& Madnick, S. E. 1990. The Elusive Silver Lining: How we fail to Learn from Software Development Failures. Sloan Management Review, 39-48.

Abul Hasan M. Shade. 1992. Al Ghazali on Economic Issues and Some Ethico-Juristis Matter Having Implications for Economic Behavior, in Reading in Islamic Economic Thought, Longman Malaysia.

Abdul Sattar. 1976. Ibn Khaldun's Contribution to Economic Thought" in: Contemporary Aspects of Economic and Social Thinking in Islam.

Abdul Qadir: Ibn Khaldun to ma'ashi khayalat “, (Economic Views of Ibn Khaldun)

Adelman, Irma, 1962. Theories of Economic Growth and Development, California: Standford University Press.

Addas, Waleed A. J. 2010. Methodology of Economic, Secular vs Islamic, A Comparative Study of Economics: From Self-Interest to 'God's Interest', IIUM Press, International Islamic University Malaysia.

Ahmad Ali: Economics of Ibn Khaldun-A Selection,

Al Ghazali, Ihya Ulumuddin, II, IV.

Al-Tahawi. 1974. Al-islami madhhaban nizaman wa wa Dirasah muqaranh. (Islamic Economics-a School of Thought and a System, a Comparative Study).

Anas Zarqa. 1980. Islamic Ekonomics: an Appoach to human Welfare. dalam Khursid Ahmad (ed.), studies in IslamicEconomics. Leicester: The Islamic Foundation, 14.

Baeck, Louis 1994. The Mediterranean tradition in economic thought. Routledge. p. 99. ISBN 0-41509301-5

Biddle, Jeff E.; Davis, Jon B.; Samuels, Warren J.. A Companion to the History of Economic Thought. Malden, MA: Blackwell

Black, L. 2002. Collaborating Across Boundaries: Theoretical,Empirical, and SimulatedExplorations (Ph.D. Dissertation).

Black, L. J., Carlile, P. R., \& Repenning, N. P. 2004. A Dynamic Theory of Expertise and Occupational Boundaries in New Technology Implementation: Building on Barley's Study of CT Scanning. Administrative Science Quarterly, 49(4), 572-607.

Boulakia: A Fourteenth Century Economist,
Brenner, Y. S. 1969. Theories of Economic development and Growth (London: George Allen and Unwin Ltd.

Donaldson, Loraine. 1984. Economic DevelopmentAnalysis and policy. St. Paul: West publishing company.

Davis, J. P., Eisenhardt, K., \& Bingham, C. B. 2007) Developing Theory Through Simulation Methods. Academy of Management Review, 32(2), 480-499.

Duhamel, F., Gutiérrez-Martínez, I., Picazo-Vela, S., \& Luna-Reyes, L. F. 2012. The Key Role of Interfaces in IT Outsourcing Relationships. International Journal of Information Technologies and Systems Approach, 5(1), 37-56.

Eisenhardt, K. 2002. Building Theories From Case Study Research. En A. M. Huberman \& M. B. Miles (Eds.), The Qualitative Research Companion. London: Sage Publications.

Eltis, Walter. 1984. The Classical theory of Economic growth London: Macmillian press.

Ezzat, S. El Alfi Doctoral dissertation on Ibn Khaldun titled, Production, Distribution and Exchange in Khaldun's Writing. 1994.

Ghaffarzadegan, N., \&Andersen, D. F.2012. Modeling Behavioral Complexities of Warning Issuance for Domestic Security: A Simulation Approach to Develop Public Management Theories. International Public Management Journal, 15(3), 337-363. doi:10.1080/10967494.2012.725566

Ghazafar, S. M. dan Abdul Azim Islahi. 1990. Economic Thought of an Arab Scholastic: Abu Hamid al-Ghazali, History of political Economy 22:2, (Durham : Duke University Press.

Ghazanfar, Mohammad, Islahi Abdul Azim. Economic ThoughtofAlGhazali. Jeddah: Scientific Publisihing Centre King Abdulaziz Univesity, 1997

Ghazanfar, S.M. Medieval Islamic Thought: Filling the "great gap" in European Economics. London: Routlegde, 2003

Glaser, B. G., \& Strauss, A. L. 1967. The Discovery of Grounded Theory: Strategies for Qualitative Research. Chicago: Aldine Publishing Company.

Hanneman, R. 1987. Computer-assisted Theory-Building. Newbury Park, CA: Sage Publications, Inc.

Hanneman, R., \& Patrick, S. 1997. On the Uses of Computer-Assisted Simulation Modeling in the Social Sciences. Sociological research Online, 2(2). 
Higgins, Benjamin. 1966. Economic Development - Principles, Problems and Policies (Allahabad: Central book depot.

Hoselitz, Bert. F.(ed). 1960. Theories of Economic Growth (The Free press of Glenco.

Hosseini, Hamid S. 2003. "Contributions of Medieval Muslim Scholars to the History of Economics and their Impact: A Refutation of the Schumpeterian Great Gap".

Ibn Taymiyya: The book of Fatawa, Hisbah fi'l-alIslam (The institution of Hisbah in Islam) and alSiyasah Shariyah fi al-Islah al-Ra'I wa'l Raiyah (Public and Private laws in Islam).

Ibn al Sabil: ishtirakiyat fi'l Islami Islam,

Islahi, Abdul Azim. 1992. Economic Concept of Ibn Taimiyyah, in Reading in Islamic Economic Thought, Longman Malaysia.

Islahi, Abdul Azim. 1996. Economic Concepts of Ibn Taymiyyah. United Kingdom: The Islamic Foundation.

Issawi Charles. 1992. Ibn Khaldun's Analysis of Economic Issues, in Reading in Islamic Economic Thought, Longman Malaysia.

Joseph J. Spengler, «Economic Thought in Islam: Ibn Khaldun,» Comparative Studies in Society and History, 6(3): (April 1964).

Luna-Reyes, L. F., \& Gil-Garcia, J. R. 2011. Using institutional theory and dynamic simulation to understand complex e-Government phenomena. Government Information Quarterly, 28(3), 29. 345. doi:10.1016/j.giq.2010.08.007

McCaffrey, D., Andersen, D. F., McCold, P., \& Kim, D. H. 1985. Modeling Complexity: Using Dynamic Simulation to Link Regression and Case Studies. Journal of Policy Analysis and Management, 4(2), 196-216.

Muhammad Hilmi Murad : Abul Iqtishad: Ibn Khaldun. That is Father of Economics: Ibn Khaldun

Muhammad Nejatullah Siddiqi. 1982. Recent Work On History Of Economic Thought In Islam, International Centre for Research in Islamic Economics King Abdulaziz University Jeddah, Saudi Arabia.

Walsham, G. 1995. Interpretive Case Studies in IS research: Nature and Method. European Journal of Information Systems, 4(2), 74-81.
Nasha't "Al-Fikr al-iqtisadi fi muqaddimat Ibn Khaldun (Economic Though in the Prolegomena of Ibn Khaldun).

Nejatullah Muhammad Ash-Shiddiqy. 1992. Islamic Economic Thought: Foundation, Evolution, and Need Direction, in Reading in Islamic Economic Thought, Longman Malaysia.

1992. Recent Works on History of Economic Thought in Islam: A Survey, Longman Malaysia.

Patrick, S. 1995. The Dynamic Simulation of Control and Compliance Processes in Material Organizations. Sociological Perspectives, 38(4), 497-518.

Rahmandad, H. 2008. Effect of Delays on Complexity of Organizational Learning. Management Science, 54(7), 1297-1312.

Rahmandad, H. 2012. Impact of Growth Opportunities and Competition on Firm-Level Capability Development Trade-offs. Organization Science, 23(1), 138-154.

Richardson, G. P., \& Pugh, A. L. 1981. Introduction to System Dynamics Modelling with Dynamo. Cambridge, MA: Productivity Press.

Repenning, N. 2002. A Simulation-Based Approach to Understanding the Dynamics of Innovation Implementation. Organization Science, 13(2), 109-127.

Richardson, George P. 1996. Problems for the Future of System Dynamics. System Dynamics Review, 12(2), 141-157.

Rifa'at Par. Ibn Khaldun Ma'ashiyat to Khalayat" (Ibn Khaldun's Views on Economics).

Rosenthal Frans. Ibn Khaldun The Muqaddimah: An Introduction to History.

Shiddiqy Boulokia. Ibn Khaldun: A Fourteenth Century Economist.

Sterman, J. D. 2000. Business Dynamics: Systems Thinking and Modeling for a Complex World. Boston: Irwin/McGraw-Hill.

Somogyi. Economic Theory in the Classical Arabic Literature, Iqtisad.

Spengler. Economic Thought of Islam: Ibn Khaldun. TB Irving. Ibn Khaldun on Agriculture.

Zainab Al-Khudairi. 1978. Symposium on Ibn Khaldun, in Egypt. 